\title{
A Consistent Data Series to Evaluate Growth and Inequality in the National Accounts ${ }^{1}$
}

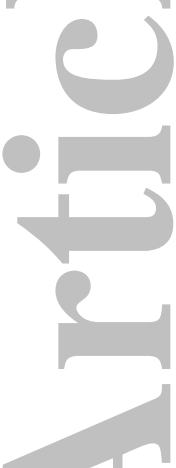

\author{
Dennis Fixler (BEA) \\ David Johnson (University of Michigan) \\ Andrew Craig (BEA) \\ Kevin Furlong (BEA)
}

Recent headlines frequently refer to rising inequality and its implication on economic growth and social welfare. Addressing the latter is difficult and requires more than simply looking at GDP, as Kuznets long ago pointed out. In this paper we focus on the importance of the income measure underlying the inequality measure when examining the relationship between GDP growth and inequality. We create a mapping using Census Bureau household survey data and Bureau of Labor Statistics (BLS) consumer expenditure data to create distributional measures of the Bureau of Economic Analysis (BEA) personal income. We show that for the period 20002012, inequality using personal income is substantively lower than inequality measured using Census Bureau money income, and the trends in both inequality and median income are different. This demonstrates the importance of using a measure a national account based measure of income when examining the relationships between inequality and growth.

Keywords: inequality, growth, national accounts

JEL Classification: E01, D31, O40

\footnotetext{
${ }^{1}$ The views expressed in this research, including those related to statistical, methodological, technical, or operational issues, are solely those of the authors and do not necessarily reflect the official positions or policies of the Bureau of Economic Analysis or the University of Michigan, or the views of other staff members. The authors thank the participants at the OECD-IARIW special conference and the anonymous referees for helpful comments. The authors accept responsibility for all errors. This paper is released to inform interested parties of ongoing research and to encourage discussion of work in progress.
}

This is the author manuscript accepted for publication and has undergone full peer review but has not been through the copyediting, typesetting, pagination and proofreading process, which may lead to differences between this version and the Version record. Please cite this article as doi:10.1111/ roiw.12324. 
Frequent headlines present rising per capita Gross Domestic Product (GDP) and yet refer to people who have not shared equally in this growth. In 2014, the New York Times stated: "Growth hasn't translated into gains in middle class income," (Irwin, 2014) and included a figure that showed the growth in per capita GDP outpacing the change in median household income between 1993 and 2013 (with per capita GDP growing over 40 percent and median household income increasing only 5 percent). This disconnect between aggregate growth and its distribution to individuals has been amplified during the past few years, fueled by the Great Recession. The relationship between macroeconomic growth and income inequality has been the focus of many recent studies (see OECD, 2011; Boushey and Hersh, 2012; Boushey and Price, 2014; OECD, 2014). However, almost 70 years ago, Kuznets (1943) in his original report on the national accounts suggested that growth in GDP was not sufficient to evaluate social welfare. This view is echoed in recent Economic Report of the President and is the theme of the Report by the Commission on the Measurement of Economic Performance and Social Progress (Stiglitz, 2009).

There is considerable agreement about the increase in inequality in the US during the past 30 years (see Congressional Budget Office (CBO), 2013; Johnson and Smeeding, 2014); there is, however, considerable disagreement regarding the relationship between inequality and growth. The most recent Economic Report of the President (Council of Economic Advisors, 2015) states that if inequality had not increased from 1973 to 2013, then (under certain assumptions) “...income for the typical household would have been 18 percent, or about $\$ 9,000$, higher." New OECD analysis suggests that income inequality has a negative and statistically significant 
impact on medium-term growth. ${ }^{2}$ Even the business community is concerned about rising inequality. A recent Standard and Poors report stated: "Our review of the data, as well as a wealth of research on this matter, leads us to conclude that the current level of income inequality in the U.S. is dampening GDP growth..." (see Standard and Poors, 2014). However, a different OECD report (OECD, 2012) suggested that “...no general consensus has emerged and the empirical evidence is rather inconclusive."

Figure 1 confirms the results from the New York Times story mentioned above that aggregate growth (using per capita income) has increased much more that median household income (from Census). This figure also highlights the impact of using alternative income measures (as from CBO, 2013) and price indexes. For example, the median household income increases 5.1 percent (using the CPI-U-RS) between 1979 and 2012, while adjusting for inflation using the PCE deflator yields a 16 percent increase. In addition, using the median before tax income from CBO yields a 34.4 percent increase (between 1979 and 2011) (see Fixler and Johnson, 2014).

\section{[ PLACE FIGURE 1 HERE ]}

This paper creates a short time series of data that can be used to determine the relationship between growth and the size distribution of income using national accounts data. As the national accounts provide the source data for discussions of economic growth, the main issue with relating growth and inequality is obtaining comparable measures of both; that is the focus of this paper. GDP is, after all, a measure of production for some time period and the corresponding measure for much of the income is the payments to the factors of production.

\footnotetext{
2 "Rising inequality by 3 Gini points, that is the average increase recorded in the OECD over the past two decades, would drag down economic growth by 0.35 percentage point per year for 25 years: a cumulated loss in GDP at the end of the period of 8.5 per cent." (See OECD, 2014)
} 
Accordingly, we examine the distribution and movement of household income, as measured by personal income. With the distributional aspects of personal income, one can examine how various changes in policy may impact households at various points in the distribution. This paper builds on Fixler and Johnson (2014) and McCully (2014) and uses the Current Population Survey (CPS) and the Consumer Expenditure (CE) Survey to construct distributional and inequality measures for the national account measure of personal income from 2000-2012. More specifically, the contribution of this paper derives from its combining the mappings and estimate in the aforementioned papers to achieve a transformation of the Census money income concept to the national accounts measure of personal income.

\section{Income Distribution and Macroeconomics}

Since the development of national accounts, the relationship between the distribution of income and economic growth has been an area of ongoing research. Kuznets (1955, pg. 27), in his famous paper on inequality and growth, stated: "The distribution of national product among the various groups is a subject of acute interest to many and is discussed at length in any half-articulate society." In conjunction with Kuznet's article, in the 1950s the Office of Business Economics, the predecessor to BEA, began producing measures of the size distribution of income in the United States. These first estimates were released in 1953 and began with estimates for 1947 (see Office of Business Economics, 1953). Similar to our method, these estimates used the CPS to account for distribution, and allocated the measure of personal income to quintiles. These estimates were regularly released in the Survey of Current Business from 19501962 (Fitzwilliams, 1964), and the last estimates were produced for 1971 (Radner and Hinrichs, 1974). Figure 2 shows the distribution of personal income by quintile and the top 5 percent for the years produced. 


\section{[ PLACE FIGURE 2 HERE ]}

As one can see, there was little change in inequality during this period with the shares remaining fairly constant over the entire period. This period has been labeled the "age of shared growth" (see CEA, 2015).

Most research examines the distribution of income using either money income from the Census Bureau (DeNavas-Walt and Proctor, 2014) or after-tax income (CBO, 2013). Recently, other researchers have also examined IRS data (Piketty and Saez, 2003). However, none of these definitions of income match the definition of personal income from the National Income and Product Accounts (NIPA). The goal of this paper is to provide consistent distributional measures of personal income that can be used to compare to the growth rates of GDP.

The interest in understanding the role of the income distribution in macroeconomics, specifically economic growth, has a long history. For example, Ricardo focused on the functional distribution of income, that is, roughly speaking, the distribution of income between labor and capital. ${ }^{3}$ The distribution of personal income, which is the focus of this paper, received later attention and now is the subject of much discussion. Intuitively, there is a relationship between these two perspectives of the income distribution. For example, the Solow growth model with its focus on saving and capital accumulation determines both capital and labor income, which then is distributed over the population. ${ }^{4}$ Kuznets' (1955) seminal paper sparked numerous studies testing his hypothesized inverted U-shaped relationship between growth and the income distribution that depended on the state of the economy-whether it was developed or

\footnotetext{
${ }^{3}$ See Sandmo (2013) for a history of economic thought on the income distribution.

${ }^{4}$ Jones (2015) uses Solow growth model, along with the Pareto distribution to examine the source of the income distribution in the top tail.
} 
less-developed. ${ }^{5}$

A metric that is commonly used to study the relationship between economic growth and inequality is GDP per capita. This measure, however, blurs the distinction between the functional/personal distributions of income because it includes both the production of goods and services (the use of capital and labor) and the income payments to the owners of capital and labor, the population. To relate growth to a notion of inequality, one can think of a simple regression in which the dependent variable is the growth in GDP per capita and the independent variable is some measure of income inequality; the Gini coefficient is commonly used. The central issue is the sign and magnitude of the coefficient on the Gini variable. There is no consensus; some studies find a negative relationship and some studies find a positive relationship. Much of the literature is devoted to trying different forms of the regression equation just described. A good summary of this literature and the robustness of the findings can be found in Dominicis, Floras and DeGroot (2008).

Another perspective on the relationship between economic growth and income inequality expands the set of explanatory variables to include social and political dimensions that may influence the relationship. More specifically, this strand of analysis looks at variables such as investment in education and fertility (see Galor and Zeira, 1993 and Cline, 1970). These studies also use GDP per capita along with measures of these non-economic dimensions.

As mentioned, currently the data used in the above described regression equation are usually on a different accounting basis. GDP is computed using national account methods; typically those described in the System on National Accounts (SNA). The inequality measure, however, is typically based on an income measure that comes from a different accounting

\footnotetext{
${ }^{5}$ See Gallo (2002) for a discussion of the empirical examining the testing the inverted U-shaped inequality hypothesis.
} 
scheme and data source. Sometimes the income measure is based on Federal Income Tax data, say, Adjusted Gross Income and sometimes it is based on the Census definition of money income. For dimensional consistency when examining the relationship between economic growth as measured by GDP and the income inequality measure, the latter should be based on the national account concept of personal income. One goal of this paper is to provide a measure of inequality that is based on personal income.

Dimensional consistency is important for two reasons. First, given that there is no single all-purpose concept of income, the income measure needs to be tailored to the issue being examined. As Fisher (1906) noted "A good definition should always conform to two tests: it must be useful for scientific analysis and it must harmonize with popular and instinctive usage." This leads to the second reason: if the issue being examined is the relationship between economic growth and income inequality then it is necessary for the concept of income and the attending measure of inequality to be on the same accounting basis as the measures of economic growth. The latter is measured by changes in GDP and so the former must be on the concept of income used in the computations of GDP. This is not a pedantic concern. As shown in Fixler and Johnson (2014) there can be a substantive difference in the measure of inequality. This difference can bear on economic policy; see for example CEA (2015) and Boushey and Price (2014). More specifically the attention is directed to how the income distribution affects fiscal policy multipliers. The underlying intuition is that the marginal propensity to consume is higher for lower income categories than for higher income categories and so the government expenditure multipliers should be higher for the lower income categories; the consequence being that redistribution from higher to lower increases economic growth. On the other hand, some would argue that redistribution from higher income to lower income via the tax code creates tax 
distortions that reduce investment and thereby reduce the economic growth. See Hobijn and Nussbacher (2015) for a recent examination of marginal and average propensities to consume for different income quintiles.

We follow the methods presented in Fixler and Johnson (2014) and McCully (2014) to allocate aggregate personal income to households. Cynamon and Fazzari (2015) and Jones (2015) use other methods. Jones (2015) uses the shares of tax income from the high income data base to allocate aggregate GDP and then determine a per capita measure for the top $0.1 \%$ and the bottom $99.9 \%$. Figure 1 in Jones (2015) shows that the mean for the top $0.1 \%$ increases $6.86 \%$ annually since 1980 , while the bottom $99.9 \%$ increases only $1.83 \% .^{6}$ Instead of using the tax shares of income, this paper uses over 65 categories of income to allocate aggregate personal income.

\section{Measuring Income}

As discussed in the NBER volume, Conference on Research on Income and Wealth (1943), there are many choices that need to be made in determining the appropriate components of income to include in a measure of income distribution. The most inclusive concept of income and consumption derives from the suggestions of Haig and Simons. Haig (1921) stated that income was "the money value of the net accretion to one's economic power between two points of time" and Simons (1938) defined personal income as "the algebraic sum of (1) the market value of rights exercised in consumption and (2) the change in the value of the store of property rights between the beginning and end of the period in question."

The focus of this paper is to evaluate the level, trend, and distribution of personal income (as measured by BEA). The SNA defines household income as “...the maximum amount that a

\footnotetext{
${ }^{6}$ Recently Piketty, et al. (2015) use a similar method to adjust the NIPA totals by the shares of income in the tax data.
} 
household or other unit can afford to spend on consumption goods or services during the accounting period without having to finance its expenditures by reducing its cash, by disposing of other financial or non-financial assets or by increasing its liabilities."

There are a multitude of income measures used by researchers and the government. Table 8.1 in Fixler and Johnson (2014) provides a comparison of income definitions across a variety of agencies and income measures. One of the main differences among the various definitions is the treatment of retirement income. Most studies of income and its distribution include the money income concept, but do not examine changes in assets, and only a few examine the impact of capital gains (e.g., CBO, 2011; CBO, 2012; Piketty and Saez, 2003). Since our purpose is to construct a distribution for the NIPA definition of personal income, we do not examine the impact of capital gains.

Before discussing our data sources and how the distribution of personal income is created, we give the broad outline of our approach. We start with Census money income because that is a household based concept and provides the basis for the distribution. Though Census money income in many ways is a more narrow definition of income, it does include variables that are not in personal income, such as retirement disbursements. Accordingly, to move from Census money income to personal income, we must first subtract from money income the components that are not in personal income and then, using the residual, add the components that are in personal income but not in money income. Unfortunately, the first step is difficult to implement because many of the money income components are commingled; that is, they contain components not in personal income as well as those in personal income. Thus, we construct an approximation to the net money income computed in the first step by adding up the components of personal income that are in money income. We call this approximation pseudo 
money income. Table 1 shows how pseudo money income is construction from the components of personal income. For example, wages and salaries is included in both pseudo money and personal income (see line 3). However, employer contributions for workers' compensation are not included in pseudo money income, but are included in personal income (see line 9).

\section{[ PLACE TABLE 1 HERE ]}

\section{Data Sources and methods}

This paper constructs distributional estimates that are fully consistent with the NIPA personal income concept, closely following the work of McCully (2014), Furlong (2014), and the OECD Expert Group on measuring Disparities in National Accounts (EGDNA). ${ }^{7}$ Previous work by Fixler and Johnson (2014) focused on creating a NIPA adjusted measure of Census money income, which kept the definition of money income - and then added other NIPA-specific income components such as health spending and imputed interest. However, because the Census definition includes income components that are not included in personal income, such as retirement disbursements, the Fixler-Johnson NIPA-adjusted income measure is still conceptually different from personal income, albeit closer than the commonly used money income concept. For example, personal income includes, but the NIPA-adjusted money income concept excludes the following: rental income from owner-occupied housing, employer fringe benefits (e.g. retirement contributions and health insurance premiums), and imputed interest on insurance policy reserve funds.

To estimate the distribution, we use the Annual Social and Economic Supplement of the Current Population Survey (CPS) integrated with the Consumer Expenditure (CE) Survey. The CPS collects data on income, while the CE collects data on both income and expenditures. CPS

\footnotetext{
${ }^{7}$ This is an ongoing working group, currently in the experimental phase of developing distributional estimates fully consistent with the SNA.
} 
and the CE surveys are nationwide household surveys designed to represent the U.S. civilian non-institutional population. There are differences between the surveys in the unit of measure, and significant differences between in frequency and design (see McCully, 2014 for more information on the surveys). The sources used for the NIPA estimates of personal income and outlays are many and diverse - sample surveys conducted by Census, administrative data from Social Security Administration and governmental benefits from other agencies.

To construct distributional estimates, personal income is first decomposed into its underlying detail level, consisting of over 65 components ranging from the more salient wages and salaries and social security disbursements to the less obvious components such as imputed interest on life insurance and pension reserve funds. Each of these components is then matched to corresponding micro data to obtain distributional information. Both CPS and CE surveys are necessary because neither one contains all the information required to define personal income. For example, only the CE contains information on the rental value of owner-occupied housing, mortgage interest, and homeowner's insurance, all of which is needed to construct the rental income of owner-occupied housing.

Although both surveys are comprehensive, covering a wide range of income and consumption variables, it is not always possible to find an exact match in the micro data. In these instances, indicator variables are constructed from the micro data which are used to distribute the NIPA aggregates across each household accordingly. For example, neither survey contains a variable for employer contributions to pension plans. However, the CPS includes a variable indicating if the person participates in a pension plan or not. This variable is used in combination with a person's wage, which is assumed to be proportional to the employer contribution. Therefore, a person with a higher wage would receive a larger share of the NIPA aggregate than 
a person with a lower wage, given that they participated in a pension plan. Similarly, the imputed interest received from depository institutions is assumed to be proportional to a household's savings and checking account - two variables obtained from the CE.

Because information is used from two surveys, personal income could not directly be estimated for each household in each survey. To overcome this problem, a synthetic data set is constructed using a statistical matching procedure, which links housing units in the CPS to units in the CE through the use of 20 common variables in both surveys. ${ }^{8} \mathrm{~A}$ CPS and CE household are assumed to be statistically identical if a distance function between the two is minimized for all possible housing combinations.

Another issue with using the survey data for the NIPA distribution is that the underlying populations covered are different. The CPS and CE surveys cover only the civilian noninstitutional population, while personal income estimates in the NIPAs cover the income (and expenditures) of those defined as U.S. residents in the national accounts, which includes nonprofit institutions serving households (NPISHs), the institutionalized population, federal civilian and military personnel stationed abroad, and persons whose usual place of residence is the U.S. who are private employees working abroad for a period of less than one year. Excluded from the NIPA definition of residents are foreign nationals who work and reside in the U.S. for part of the year and foreign nationals studying in the U.S. In addition, NIPA estimates include the income of those who died during the preceding year, who are not captured in the CPS. Excluding NPISHs income and accounting for transfers between households and NPISHs gives a measure of household income, which will be used for the integration of the micro and macro

\footnotetext{
${ }^{8}$ Statistical matching first began to be widely used in the early 1970s through the work of Budd (1971), Okner (1972), Ruggles and Ruggles (1974), Radner (1981), Barr and Turner (1981), Rodgers and DeVol (1984), Rubin (1986) and more recently by Kadane (2001), D'Orazio et al. (2001), Moriarity and Scheuren (2001 and 2003), and Denk and Hackl (2003).
} 
estimates.

In order to align the NIPA population with that of the household surveys, we adjust the NIPA aggregates to align with the population covered in the household surveys. In most cases this means removing certain population groups from the estimates, though in a couple of instances it means adding population groups. ${ }^{9} \quad$ (See Table 1 for the coverage ratios and McCully (2014) for more details on their construction.)

The next step is to construct the totals of each income component defined by the NIPA definition using the synthetic data and calculate scaling factors using the actual NIPA totals. We then apply these factors to the underlying micro-data, hence ratio adjusting each income component for each household using the component specific scaling factors.

Specifically, consider household $\mathrm{i}$, with income, $\mathrm{y}_{\mathrm{i}}=\sum_{\mathrm{jk}} \alpha_{\mathrm{j}} \mathrm{y}_{\mathrm{jki}}$, where the scaling factors, $\alpha_{\mathrm{j}}$, depend on the source, $\mathrm{j}$, of income (e.g., wages or dividends) and are given by the ratio of aggregate personal income to aggregate income in the surveys (either CPS or CE in the integrated data set). Here $\alpha_{\mathrm{j}}=\mathrm{Y}_{\mathrm{j}} / \mathrm{X}_{\mathrm{j}}$, where $\mathrm{Y}_{\mathrm{j}}$ is the aggregate for source $\mathrm{j}$ in the personal income measure (in the NIPAs) and $\mathrm{X}_{\mathrm{j}}$ is the aggregate for source $\mathrm{j}$ in the integrated data. This procedure increases each household's income by source and the new scaled household data is then used to obtain distribution measures. ${ }^{10}$

To illustrate, consider only one source of income, such as wages. Then the scaled income for household $\mathrm{i}$ is equal to [NIPA wages/CPS wages] x CPS wages for household $\mathrm{i}$. Additional sources of income would be similarly calculated and added to the total. This procedure generates

\footnotetext{
${ }^{9}$ The following population groups are removed from the macro estimates - Institutionalized, Decedents, U.S. residents not physically present in the U.S., U.S. government civilian and military personnel stationed abroad, private employees whose usual place of residence is the U.S. who are on foreign assignment for a period of less than one year, and domestic military living on post. Alternatively, the following groups are added to the macro estimates -- foreign nationals studying in the U.S.; foreign temporary agricultural and nonagricultural workers living in the U.S.; foreign professionals temporarily residing in the U.S.

${ }^{10}$ The simple ratio-adjustment mentioned above is for $\alpha_{\mathrm{j}}=\alpha$ for all sources.
} 
a NIPA-based scaled income series for households in the CPS and thereby yields an NIPA based income distribution.

One limitation of the above approach is that we assume that the levels of under-reporting (and the difference between survey reports and NIPA measures) are the same for all households. Hence, every household receives the same scaling factor for each source of income. However, it is likely that different households have different levels of under-reporting. Research has shown that there is a large underreporting at the top of the distribution (see Sabelhaus et al., 2015).

We follow this procedure for 2000 to 2012 and obtain annual estimates for household money income (see DeNavas-Walt and Proctor, 2014) and all the components, along with personal income measure and all of the additional components. Table 1 describes the income sources included in the various income definitions.

All estimates in the tables have been converted to 2006 dollars using the PCE price index, and all measures of inequality (e.g., Gini coefficient) have also been household size adjusted using an equivalence scale given by the square root of family size. ${ }^{11}$ These methods are similar to those recommended by the new OECD expert group on disparities in the national accounts (see Fesseau and Mattonetti, 2013).

\section{Results}

The different definitions of income are shown in Table 2. The top row shows the money income used by the Census Bureau. Our measure of pseudo income is shown below, and the right column shows the scaled values using the adjustments discussed above. Similar to Fixler and Johnson (2014), the scaled pseudo income is larger than money income. Not-scaled pseudo income is less than money income due to the exclusion of retirement income from the NIPA

11 The square root of family size is often used in international comparisons. We have also compared these results to those using the OECD equivalence scale. 
concept and the comingled factors mentioned above. Using the NIPA totals to scale pseudo income increases it by 28 percent (which is 20 percent larger than money income). Personal income is much larger than pseudo income due to the inclusions of financial factors (such as imputed interest and imputed rent), health factors (such as the cost of Medicare and Medicaid), other transfers (such as food stamps (SNAP) and Energy assistance), and the exclusion of contributions (such as employer and employee FICA contributions). As a result, personal income is 54 percent larger than money income (and scaling increases it by 24 percent).

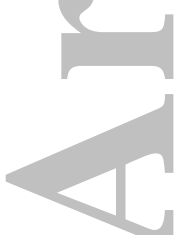

[ PLACE TABLE 2 HERE ]

\section{[ PLACE TABLE 3 HERE ]}

Table 3 shows the various measures at different points in the distribution - mean, median, $10^{\text {th }}, 90^{\text {th }}$ and $95^{\text {th }}$ percentile for the $2000-2012$ period. The first two panels of this table show that our scaled pseudo income concept is greater than Census money income. The figures indicate that our pseudo money income is a reasonable approximation of Census money income. The personal income amounts represent the scaled pseudo income adjusted further by the finance, health and other transfer adjustment factors. Note that while Census money income and pseudo income have declined across the board, personal income has increased.

As expected the incorporation of scaling increases the mean and median of pseudo money income and thereby increases the difference between pseudo income and Census money income. More specifically, the median Census money income falls 6.2 percent over the period, and the median pseudo money income falls 3.2 percent. In contrast, the median personal income increases 4.0 percent. This pattern holds for the means as well. Using the mean and median we can compute the Pierson measure of skewness for Census money income and personal income. The measure for Census money income is about 0.7 for each year and for personal income it is 
about 0.8. Thus both distributions are stable in terms of skewness and skewed toward higher incomes.

Using these new measures, we can construct the distributions by quintile and compare them to those shown in Figure 2. Figure 3 shows that the shares of income by quintile are fairly stable over this short period. Showing the increase in inequality over the period, the top shares are slightly higher in 2012 than in 2000 and the bottom shares are smaller in 2012. Over the period of the Great Recession, the share of the top 5 percent falls, but then comes back up between 2011 and 2012.

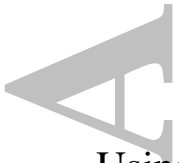

\section{[ PLACE FIGURE 3 HERE ]}

Using these shares and the personal income measures, we can construct a measure similar to Jones (2015). Figure 4 shows the mean for the top 5 percent and bottom 95 percent using the shares presented in Figure 3, total personal income and the population for each component. Following Jones (2015), this figure uses data from the World Top Income Database (WTID) along with our measures. ${ }^{12}$ Similar to Jones (2015), this Figure shows that, between 1979 and 2012, using the WTID yields a much larger increase in income for the top 5 percent than the bottom 95 percent (95 percent and 49 percent). As expected, the tax data also shows much higher shares on income for the top 5 percent of the population compared to the top 5 percent using our methods. This is mainly due to the non-tax income components included in personal income. The WTID shows an increase in the top 5 percent of 27 percent between 2000 and 2012, compared to 19 percent for personal income. The trends surrounding the recession, however, are similar, with both falling between 2007 and 2009 and rising in 2011 and 2012.

Piketty et al. (2015) similarly use the WTID and follow a similar approach to ratio adjust

\footnotetext{
${ }^{12}$ Figure 1 in Jones (2015) shows the trends in the mean GDP for the top 0.1 percent and the bottom 99.9 percent, while our paper examines personal income for the top 5 percent and bottom 95 percent so that it can be compared to the shares found using the microdata (as the sample size for the top 0.1 percent is too small).
} 
the various income components. Their income measure is pre-tax income, which does not include government transfers (such as health care) and includes retirement income on a distribution basis (instead of an accrual basis as in personal income). They find that the top 10\% and $5 \%$ shares (and the means) grow dramatically over the past few decades, while the mean of the bottom 90 percent increases less than 1 percent annually 1979. And between 2000 and 2012 they find that the mean national income for the bottom $90 \%$ does not increase (compared to our increase 6.5 percent mainly due to the inclusion of government benefits).

\section{[ PLACE FIGURE 4 HERE ]}

Figure 5 shows the Gini coefficients from these adjusted measures. The Gini coefficient is on the left axis for the different income measures and the right axis is for GDP per capita. For (n)

this period, there are differences in the relationships between GDP per capita and the different income Gini coefficients: GDP per capita is strongly positively correlated with personal income, weakly positively correlated with pseudo income and weakly negatively correlated with Census money income. These relationships may be different over multiple decades, but they are consistent with the absence of a consensus about the relationship between GDP per capita movements and income inequality.

\section{[ PLACE FIGURE 5 HERE ]}

Figure 6a depicts the incremental changes in the Gini coefficients as the concept of income moves from pseudo to personal income. Pseudo income plus financial income includes the interest and dividends earned on behalf of households (including pensions), while the actual interest and dividends is included in pseudo income. Transfers includes the non-cash transfers to households from the government (e.g., food stamps), and health transfers are basically the value of Medicaid and Medicare (see Table 1 for components of each definition). Qualitatively the 
ordering of the adjustments does not impact the results, only the point at which the impact on the trend is observed. Figure 6 a also shows that the addition of transfers and health related adjustments have the greatest impact on the Gini coefficients. In fact, over the period, the pseudo income Gini increases 6.9 percent, while the Gini for personal income increases half as much at 3.2 percent (with the main difference coming from transfers and health. (The Gini for pseudo income + financial increases 7.2 percent.) In Figure 5, the Census money income Gini increases 4.8 percent between 2000 and 2012 .

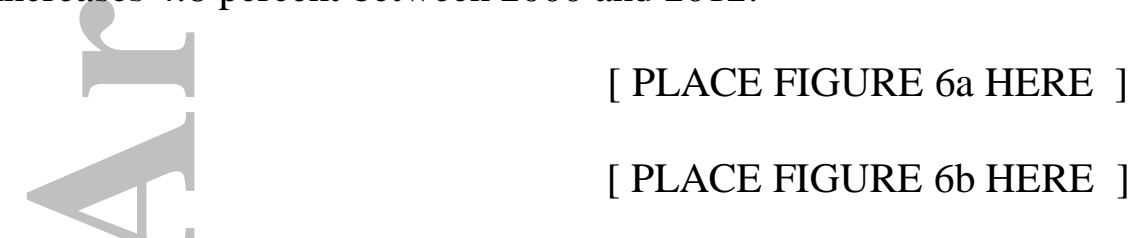

Similar to Burkhauser et al. (2010) and Meyer and Sullivan (2011), including the imputations for health care benefits yields an even greater increase in the mean and median and a smaller increase in inequality. It is clear that the social safety net, the combination of the transfers and health expenditures, substantially reduce the changes in the Gini coefficient for the period. This result is qualitatively similar to the result in Fixler and Johnson (2014).

One can construct a measure of money income plus the imputed value of Medicare and Medicaid (see Hardy and Johnson, 2015). This measure increases 0.5\% between 2006 and 2012, less than the similar pseudo income plus health. In fact, this measure is fairly flat between 1990 and 2012, while the money income measure increases. Hardy et al. (2015) also produce an extension of Fixler and Johnson (2014) from 1979-2012 and find results similar to those shown here - using only money income (or pseudo) the scaling slightly increases both the level and trends in inequality.

Using these estimates of the Gini coefficient and the mean income, one can construct a measure of social welfare as depicted in Figure 6b (see Fixler and Johnson, 2014). Jorgenson 
and Schreyer (2015) follow a similar procedure as that presented here to ratio adjust components of personal consumption expenditures to obtain an index of equality (or inequality). Using this index and a measure of mean per equivalent spending, they also produce a social welfare measure. For personal income over the period of 2007 - 2012, the rising average income has no effect on the Social Welfare Function (SWF) because of the rise in the Gini coefficient. For Money Income, the decrease in average income and an increase in its Gini lead to a decrease in SWF. The decrease in SW is mitigated by the modest rise in the Gini coefficient. For Pseudo Money, the increase in Gini coefficient decreases the SWF because average Pseudo Income is relatively flat.

Our focus is to construct a distribution of income based on the national accounts concept of personal income. We can also use this measure to evaluate the distribution of income by various demographic groups. For example, Figure 7 shows the median income by age group for three income measures. All three measures show the common life-cycle pattern for income -income increasing in early years, peaking in the middle years and falling in retirement age. Even though these income concepts treat retirement contributions and distributions differently (and Medicare benefits), personal income for the elderly has a similar relationship to the income of other age groups as the relationship for money income.

\section{[ PLACE FIGURE 7 HERE ]}

\section{Conclusions}

Sixty years ago, Kuznets (1955) stated: "Today, there is increased concern about the skewed income distribution, and the increase in skewness over time." He also argued that the distribution of income must be linked to the measure of national income. Building on the earlier work of BEA that also occurred sixty years ago, we construct a micro data set that can produce a 
consistent measure of income that can be used to examine the income distribution. We find that these measures yields different levels and trends in the median and inequality than obtained using the usual money income measure. While these relationships may not hold for longer time periods, they are consistent with the absence of a consensus about the relationship between GDP per capita movements and income inequality. It is only using these measures of income that are consistent with the NIPA income measures that one can accurately examine the relationships between inequality and growth. The results in this paper may provide a framework for developing measures of median personal income, GDI and their distribution that could be produced on a regular basis.

Our work also contributes to the new OECD international project on measuring distribution in the national accounts and the OECD initiative on inclusive growth. In support of the OECD Expert Group on Distribution in the National Accounts, the results of this paper will be expanded to examine the distribution of disposable personal income and consumption expenditures, and include distributions by demographic characteristics. ${ }^{13}$

Future work includes the analysis of the matched household data with the tax records to obtain a more complete measure of income underreporting (see Fixler and Johnson, 2014). A more complete method of determining the aggregate impacts of the joint distribution of income and consumption requires similar decompositions of PCE and personal income that rely on the distribution of the household survey data (for a similar approach see Jorgensen and Schreyer, 2015). In addition, this project will be expanded to incorporate the Integrated Macro Accounts and construct consistent distributions of income, consumption and wealth. ${ }^{14}$ With these

\footnotetext{
${ }^{13}$ Preliminary results show that the Gini for disposable personal income is lower than the Gini for personal income, while the trends during the 2006-2012 period are similar.

${ }^{14}$ Fisher, et al. (2015) compute the joint distribution of income, consumption and wealth using the Survey of Consumer Finances.
} 
complete distributions, we will be able to produce estimates of the average propensity to consume by quintiles of income and further examine the macroeconomic relationships between growth and the distribution of income and consumption. This information, along with the attending marginal propensities to consume is relevant for the policy discussions that rely on the magnitude of the expenditure multipliers for different income categories.
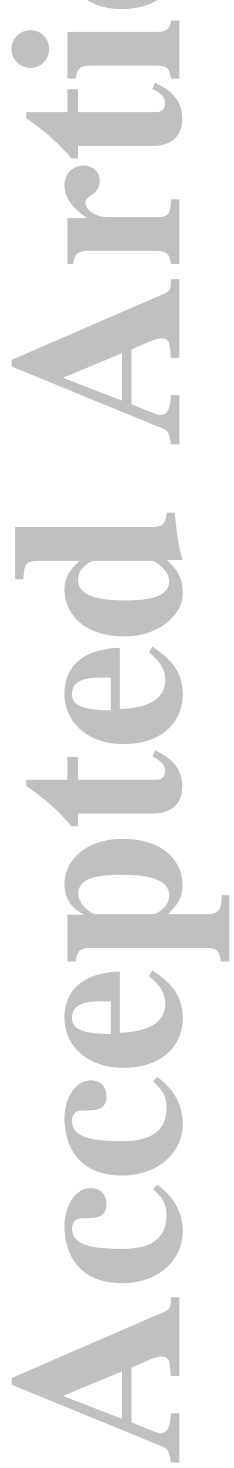


\section{References:}

Atkinson, A., T. Piketty and E. Saez, "Top Incomes in the Long Run of History, Journal of Economic Literature, 49:1, pp 3-71, 2011.

Bar, R. S. and S. J. Turner, "Microdata File Merging Through Large-Scale Network Technology." Mathematical Programming Study 15: 1-22, 1981.

Budd, E. C, "The Creation of a Microdata File for Estimating the Size Distribution of Income. Review of Income and Wealth 17: 317-333, 1971.

Budd, E. and D. Radner, "The Bureau of Economic Analysis and Current Population Survey Size Distributions: Some Comparisons for 1964," in The Personal Distribution of Income and Wealth, James D. Smith, ed., NBER 1975.

Buhmann, B., L. Rainwater, G. Schmauss, and T. Smeeding, "Equivalence Scales, Well-being, Inequality, and Poverty: Sensitivity estimates across Ten Countries Using the Luxembourg Income Study Database," Review of Income and Wealth, 34, 115-142, 1988.

Burkhauser, R., J. Larrimore, J. and K. Simon, “A "Second Opinion" On The Economic Health Of The American Middle Class” NBER Working Paper 17164, 2012.

Boushey, H. and A. Hersh, The American Middle Class, Income Inequality, and the Strength of Our Economy New Evidence in Economics," Center for American Progress report, May 2012.

Boushey, H. and C. Price, "How are Economic Inequality and Growth Connected?," Washington Center for Equitable Growth, October 2014.

Cline, W.R., "The Potential Effect of Income Redistribution on Economic Growth in Six Latin American Countries", Discussion Paper No. 13, Woodrow Wilson School, Princeton University, 1970.

Conference on Research in Income and Wealth, "Comparability and Deficiencies of Existing Data and the Construction of a Size Distribution for the United States," in Income Size Distributions in the United States, Part I, NBER, 1943.

Congressional Budget Office, "The Distribution of Household Income and Federal Taxes, 2008 and 2009, CBO report, 2012.

Congressional Budget Office, "The Distribution of Household Income and Federal Taxes, 2010, CBO report, 2013.

Council of Economic Advisors, Economic Report of the President, 2015, GPO, 2015.

Cynamon, B.Z and S.M. Fazzari, "Household Income, Demand, and Saving: Deriving Macro 
Data with Micro Data Concepts," Review of Income and Wealth, May 2015.

Denk, M. and P. Hackl, "Data integration and Record Matching: An Austrian Contribution to Research in Official Statistics." Austrian Journal of Statistics 32: 305:321, 2003.

D'Orazio, M., M. Di Zio, and M. Scanu, "Statistical Matching: A Tool for Integrating Data in National Statistical Institutes." Procedings of the Joint ETK and NTTS Conference for Official Statistics. Crete, 2001.

de Domininics, L., R. J. G. Florax, and H. de Groot, “A Meta-Analysis on the Relationship between Income Inequality and Economic Growth" Scottish Journal of Political Economy, 55:005, 654-682, 2008.

DeNavas-Walt, C. and B. D. Proctor, Income and Poverty in the United States: 2013, U.S. Census Bureau, Current Population Reports, P60-249, U.S. Government Printing Office, Washington, DC, 2014.

Fesseau, M., and M-L. Mattonetti, "Distributional Measures across Household Groups in a National Accounts Framework," Working Paper n 53 , Paris: OECD. http://www.oecdilibrary.org/economics/oecd-statistics-working-papers_18152031, 2013.

Fisher, I., The Nature of Capital and Income, New York, Macmillan, 1906.

Fisher, J., D. Johnson, and T. Smeeding, "Inequality of Income and Consumption: Measuring the Trends in Inequality from 1984-2011 for the Same Individuals," Review of Income and Wealth, online release, 2014.

Fisher, J., D. Johnson, J. Thompson, and T Smeeding, "Inequality in 3D: Income, Consumption and Wealth, NBER presentation, July 2015.

Fitzwilliams, J.M., "Size Distribution of Income in 1963," Survey of Current Business, Vol. 44, No. 4, April 1964.

Fixler, D. and Johnson, D., "Accounting for the Distribution of Income in the US National Accounts" in Measuring Economic Stability and Progess, D. Jorgenson, J. S.Landefeld, and P. Schreyer, editors, Chicago: University of Chicago Press, 2014.

Furlong, K. "Synthetic Data - Unconstrained Statistical Matching: Technical Appendix, BEA unpublished document, 2012.

Gallo, C., Economic Growth and Income Inequality: Theoretical Background and Empirical Evidence", Working Paper No. 119, Development Planning Unit, University College, London, 2002.

Galor, O. and J. Zeira, "Income Distribution and Macroeconomics," The Review of Economic Studies,” 60: 35-52, 1993. 
Goldsmith, S., 1955, "Income Distribution in the United States, 1950-53," Survey of Current Business, March 1955.

Goldsmith, S., "Size Distribution of Personal Income, 1956-59," Survey of Current Business, April 1960.

Goldsmith, S., "Changes in the Size Distribution of Income," The American Economic Review 47:2, pp 504-518, 1957.

Goldsmith, S., "The Relation of Census Income Distribution Statistics to Other Income Data," in An Appraisal of the 1950 Census Income Data, CRIW ed, NBER, 1958.

Haig, R. M., "The Concept of Income-Economic and Legal Aspects". The Federal Income Tax. New York: Columbia University Press. pp. 1-28, 1921.

Hardy, B., Gindelsky, M., Fixler, D., and Johnson, D. 2015. "Inequality in America: The Role of National Income, Household Income, and Transfers," BEA unpublished working paper

Hobijn, B. and Nussbacher, A., "The Stimulative Effect of Redistribution," FRBSF Economic Letter 2015-21, June 29, 2015.

Irwin, N., "You Can't Feed a Family with GDP," New York Times, Sept 16, 2014.

Johnson, D. and T. Smeeding, "Income Distribution and Inequality: Measurement Issues," in The International Encyclopedia of the Social and Behavioral Sciences, $2^{\text {nd }}$ ed., 2014.

Jones, C., "Pareto and Piketty: The Macroeconomics of Top Income and Wealth Inequality." Journal of Economic Perspectives, 29(1): 29-46, 2015.

Jorgenson, D. W., "Aggregate Consumer Behavior and the Measurement of Social Welfare," Econometrica, 58:5, pp. 1007-1040, 1990.

Jorgenson, D. W. and P. Schreyer, "Measuring Individual Economic Well-Being and Social Welfare within the Framework of the System of National Accounts," OECD/IARIW Conference paper, 2015.

Kadane, J. B., "Some Statistical Problems in Merging Data Files." Journal of Official Statistics 17: 423-433, 2001.

Katz, A., "Explaining Long-term Differences between Census and BEA Measures of Household Income,” BEA Working paper, 2012.

Kuznets, S., "Economic Growth and Income Inequality," The American Economic Review, Vol. 45, No. 1, pp. 1-28, 1955

McCully, C., "Integration of Micro and Macro Data on Consumer Income and Expenditures," in Measuring Economic Stability and Progess, D. Jorgenson, J. S.Landefeld, and P. 
Schreyer, editors, Chicago: University of Chicago Press, 2014.

Meyer, B. and J. Sullivan, "The Material Well-Being of the Poor and Middle Class Since 1980," AEI Working Paper \#2011-04, 2011.

Moriarity, C. and F. Scheuren, "Statistical Matching: A Paradigm for Assessing the Uncertainty in the Procedure." Journal of Official Statistics 17: 407-422, 2001.

Moriarity, C. and F. Scheuren, “A Note on Rubin's Statistical Matching Using File Coneatenation with Adjusted Weights and Multiple Imputations." Journal of Business and Economic Statistics 21: 65 - 73, 2003.

OECD, Divided We Stand: Why Inequality Keeps Rising, OECD Publishing, 2011.

OECD, "Reducing Income inequality while boosting economic growth: Can it be done?" in Economic Policy Reforms 2012, OECD, 2012.

OECD, "Focus on Inequality and Growth - December 2014." Online access www.oecd.org/social/inequality-and-poverty.htm , 2014.

Office of Business Economics, Income Distribution in the United States by Size, 1944-1950, Washington: U.S. GPO, 1953.

Okner, B. A., "Constructing a New Data Base from Existing Microdata Sets: The 1966 MERGE File." Annals of Economic and Social Measurement 1, 1972.

Piketty, T., Capital in the Twenty-First Century, Cambridge: Harvard University Press, 2014.

Piketty, T, and E. Saez, "Income Inequality in the United States, 1913-1998," Quarterly Journal of Economics, 118(1), 1-39, 2003.

Piketty, T, E. Saez, and G. Zucman, "Distributional National Accounts: Methods and Estimates for the United States since 1913," NBER Presentation, July 2015.

Sabelhaus, J., D. Johnson, S. Ash, D. Swanson, T. Garner, J. Greenlees, and S. Henderson, "Is the Consumer Expenditure Survey Representative by Income?" in Improving the Measurment of Consumer Expenditures, C. Carroll, C., T. Crossley, and J. Sabelhaus, editors, University of Chicago Press, 2015.

Radner, D.B., and J. Hinrichs, "Size Distribution of Income in 1964, 1970 and 1971, Survey of Current Business, April 1974.

Radner, D. B., "An Example of the use of Statistical Matching in the Estimation and Analysis of the Size Distribution of Income." The Review of Income and Wealth 27: 211-242, 1981.

Rodgers, W. L., "An Evaluation of Statistical Matching." Journal of Business and Economic Statistics 2: 91-102, 1984. 
Rubin, D. B., "Statistical Matching Using File Concatenation with Adjusted Weights and Multiple Imputations.” Journal of Business and Economic Statistics 4: 87-94, 1986.

Ruggles, N. and R. Ruggles, "A Strategy for Merging and Matching Microdata Sets." Annals of Economic and Social Measurement 3: 353-371, 1974

Saez, E. and G. Zucman, "Wealth Inequality in the United States since 1913: Evidence from Capitalized Income Tax Data,” NBER Working Paper 20625, 2014.

Sandmo, A., The Principal Problem in Political Economy: Income Distribution in the History of Economic Thought", Norwegian School of Economics, available at SSRN: http://ssrn.com/abstract=2337488, 2013.

Simons, H., Personal Income Taxation: the Definition of Income as a Problem of Fiscal Policy. Chicago: University of Chicago Press, 1938.

Standard and Poors, "How Increasing Income Inequality Is Dampening U.S. Economic Growth, And Possible Ways To Change The Tide," S\&P Economic Research, Aug 2014.

Stiglitz, J.E., A. Sen, and J. Fitoussi, Report by the Commission on the Measurement of Economic Performance and Social Progress. United Nations Press, 2009

Yellen, J., "Perspectives on Inequality and Opportunity from the Survey of Consumer Finances," Remarks at the Conference on Economic Opportunity and Inequality, Federal Reserve Bank of Boston, 2014.

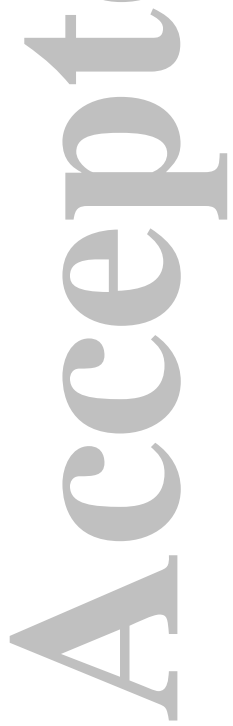




\section{Tables and Figures}

Table 1: Income Definitions, Data Source, Allocation Method, and Coverage Ratios

\begin{tabular}{|c|c|c|c|c|c|c|c|c|c|}
\hline & \multirow[b]{2}{*}{ Income Component } & \multicolumn{5}{|c|}{ Income Definitions: Components Included**** } & \multirow[b]{2}{*}{$\begin{array}{c}\text { Data } \\
\text { Source* }^{*}\end{array}$} & \multirow[b]{2}{*}{$\begin{array}{l}\text { Allocation } \\
\text { Method }^{* *}\end{array}$} & \multirow[b]{2}{*}{$\begin{array}{l}\text { Coverage } \\
\text { Ratio }\end{array}$} \\
\hline ine & & $\begin{array}{l}\text { Pseudo } \\
\text { Money }\end{array}$ & $\begin{array}{c}\text { Pseudo } \\
\text { Money + } \\
\text { Financial }\end{array}$ & $\begin{array}{c}\text { Pseudo } \\
\text { Money + } \\
\text { Financial + } \\
\text { Transfers }\end{array}$ & $\begin{array}{c}\text { Pseudo } \\
\text { Money + } \\
\text { Financial + } \\
\text { Transfers + } \\
\text { Health*** }\end{array}$ & $\begin{array}{c}\text { Disposable } \\
\text { Personal } \\
\text { Income }\end{array}$ & & & \\
\hline 1 & \multicolumn{9}{|l|}{ Personal Income } \\
\hline 3 & Wage and salaries & YES & YES & YES & YES & YES & CPS & A & 0.99 \\
\hline 4 & \multicolumn{9}{|l|}{ Supplements to wages and salaries } \\
\hline 5 & \multicolumn{9}{|l|}{ Employer contributions for employee pension and insurance funds } \\
\hline 6 & Pension plans & NO & YES & YES & YES & YES & CPS & $\mathrm{C}$ & 0.97 \\
\hline 7 & Group health insurance & NO & NO & NO & YES & YES & CPS & C & 0.99 \\
\hline 8 & Group life insurance & NO & YES & YES & YES & YES & CPS & C & 0.98 \\
\hline 9 & Workers' compensation & NO & NO & YES & YES & YES & CPS & $\mathrm{C}$ & 0.99 \\
\hline 10 & Supplemental unemployment & NO & NO & YES & YES & YES & CPS & C & 0.99 \\
\hline 11 & \multicolumn{9}{|l|}{ Employer contributions for government social insurance } \\
\hline 12 & Old-age, survivors, disability, and hospital insurance & NO & NO & NO & YES & YES & CPS & $A$ & 0.99 \\
\hline 13 & Military medical insurance & NO & NO & NO & YES & YES & CPS & $\mathrm{E}$ & 1.00 \\
\hline 14 & Other & NO & NO & YES & YES & YES & CPS & C & 0.99 \\
\hline 15 & \multicolumn{9}{|l|}{ Proprietors' Income with inventory valuation and capital consumption adjustments } \\
\hline 16 & Farm & YES & YES & YES & YES & YES & CPS & A & 0.99 \\
\hline 17 & Nonfarm & YES & YES & YES & YES & YES & CPS & A & 0.99 \\
\hline 18 & \multicolumn{9}{|l|}{ Rental income of persons with capital consumption adjustment } \\
\hline 19 & Other private business & YES & YES & YES & YES & YES & CPS & A & 0.98 \\
\hline 20 & Rental income from owner-occupied housing & NO & YES & YES & YES & YES & $\mathrm{CE}$ & C & 0.98 \\
\hline 21 & \multicolumn{9}{|l|}{ Personal income receipts on assets } \\
\hline 22 & Monetary interest income & YES & YES & YES & YES & YES & CPS & A & 0.98 \\
\hline 23 & Imputed interest income & NO & YES & YES & YES & YES & $\mathrm{CE}$ & C & 0.98 \\
\hline 24 & Personal dividend income & YES & YES & YES & YES & YES & CPS & A & 0.98 \\
\hline 25 & \multicolumn{9}{|l|}{ Personal current transfer receipts } \\
\hline 26 & \multicolumn{9}{|l|}{ Government social benefits to persons } \\
\hline 27 & Social security & YES & YES & YES & YES & YES & CPS & A & 0.95 \\
\hline 28 & Unemployment insurance & YES & YES & YES & YES & YES & CPS & A & 0.99 \\
\hline 29 & Other & YES & YES & YES & YES & YES & CPS & A & 0.99 \\
\hline 30 & State $\&$ local employment $\&$ training & YES & YES & YES & YES & YES & CPS & $\mathrm{E}$ & 0.98 \\
\hline 31 & Supplemental Nutrition Assistance Program (SNAP) (formerly Food Stamps) & NO & NO & YES & YES & YES & CPS & A & 0.98 \\
\hline 32 & WIC Food & NO & NO & YES & YES & YES & CPS & $\mathrm{E}$ & 0.99 \\
\hline 33 & Energy assistance & NO & NO & YES & YES & YES & CPS & A & 0.99 \\
\hline 34 & Refundable tax credits & NO & NO & YES & YES & YES & CPS & $A$ & 0.99 \\
\hline 35 & Retired military personnel $\&$ dependents at nonmilitary facilities & NO & NO & YES & YES & YES & CPS & $\mathrm{E}$ & 0.99 \\
\hline 36 & Medicare & NO & NO & NO & YES & YES & CPS & $A$ & 0.71 \\
\hline 37 & Medicaid & NO & NO & NO & YES & YES & CPS & A & 0.70 \\
\hline 38 & Health, other & NO & NO & NO & YES & YES & CPS & $E$ & 1.00 \\
\hline 39 & \multicolumn{9}{|l|}{ Payments to persons (net) } \\
\hline 40 & Other current transfer receipts, from business (net) & NO & NO & YES & YES & YES & $\mathrm{CE}$ & C & 0.98 \\
\hline 41 & Household current transfer receipts from NPISHs & YES & YES & YES & YES & YES & $\mathrm{CE}$ & C & 0.98 \\
\hline 42 & \multicolumn{9}{|l|}{ Transfers between households } \\
\hline 43 & Alimony received & YES & YES & YES & YES & YES & CPS & A & 1.00 \\
\hline 44 & Child support received & YES & YES & YES & YES & YES & CPS & A & 1.00 \\
\hline 45 & Less: alimony paid & NO & NO & YES & YES & YES & $\mathrm{CE}$ & A & 1.00 \\
\hline 46 & Less: child support paid & NO & NO & YES & YES & YES & CE & A & 1.00 \\
\hline 47 & Less: Contributions for government social insurance & NO & NO & YES & YES & YES & $\mathrm{CPS} / \mathrm{CE}$ & $\mathrm{A} / \mathrm{C}$ & 0.99 \\
\hline 48 & Less personal current taxes & NO & NO & NO & NO & YES & $\mathrm{CPS} / \mathrm{CE}$ & A & 0.97 \\
\hline 49 & Equals: Disposable Personal Income & & & & & & & & \\
\hline
\end{tabular}


Figure 1: Changes in growth and income using various measures $(1979=1) *$

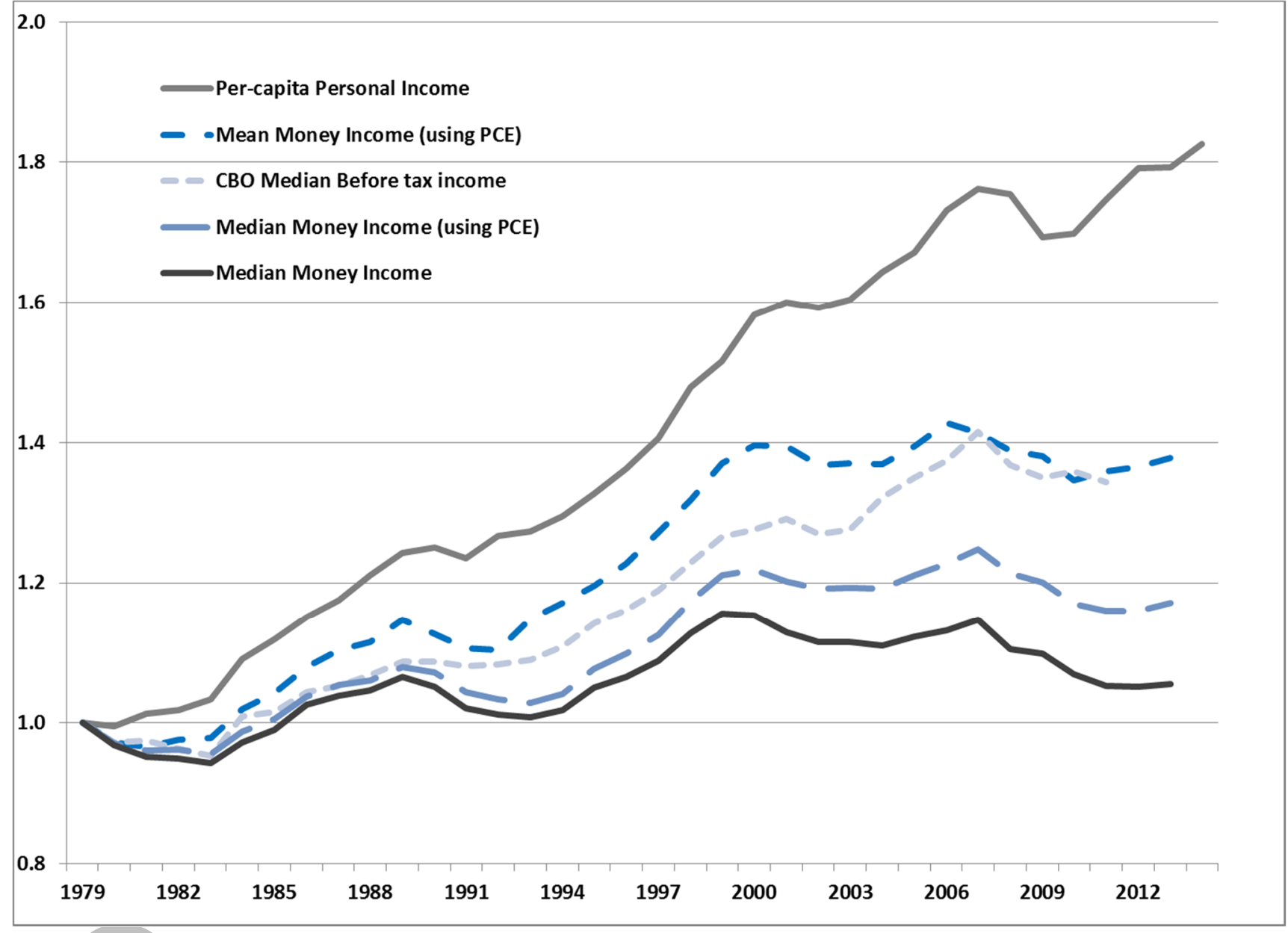

*Income metrics are not equivalized.

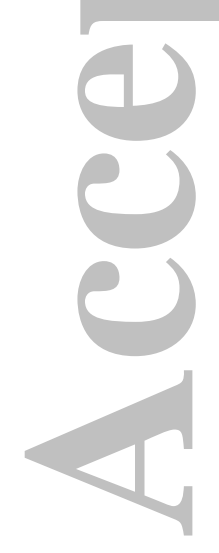

This article is protected by copyright. All rights reserved. 
Figure 2: Shares of Personal Income by Quintile and top 5 percent, 1929-1971*

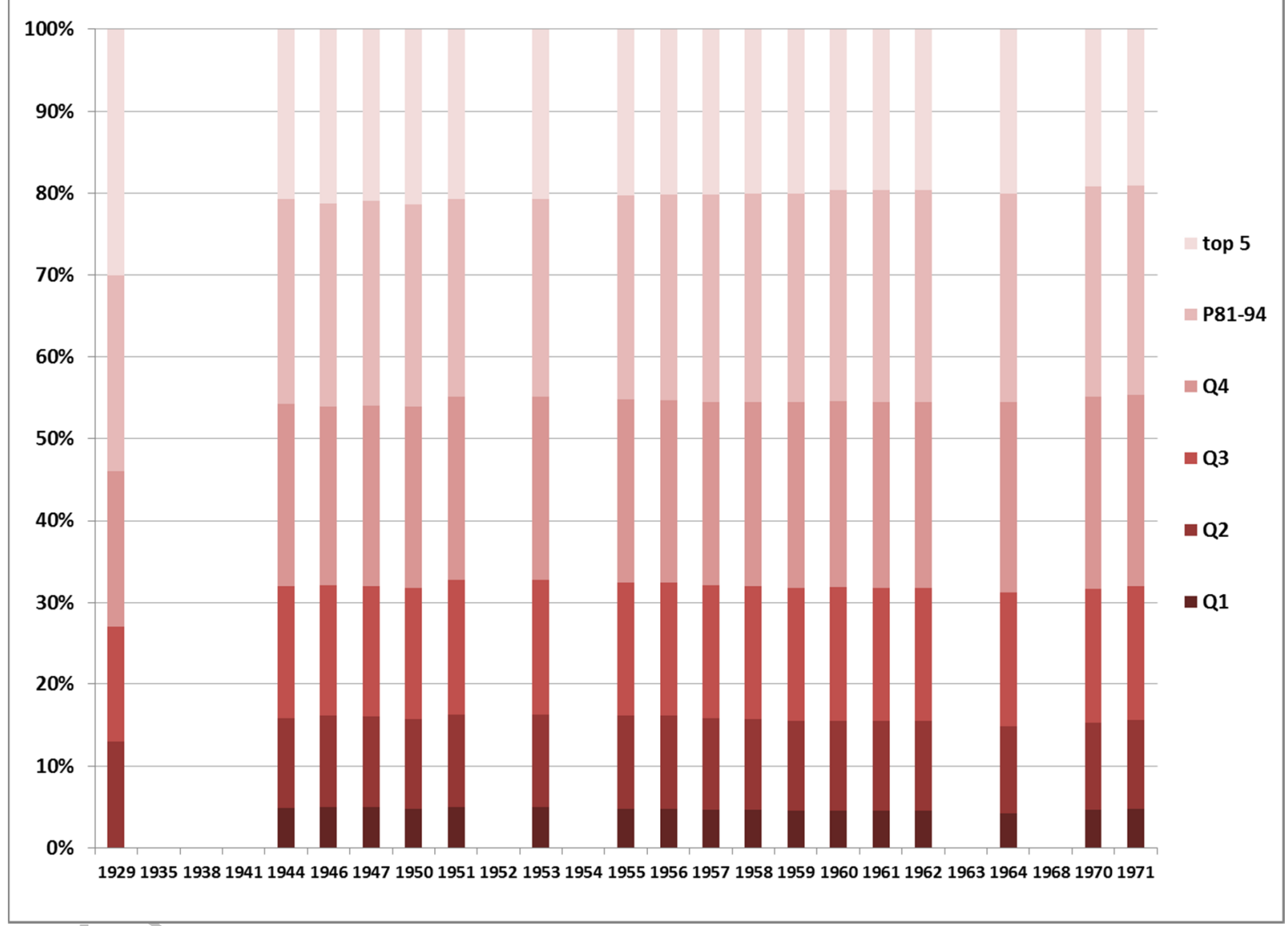

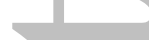

*Income metrics are not equivalized.

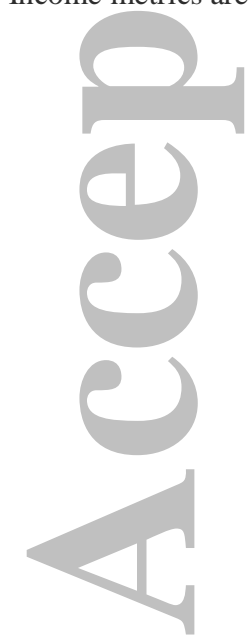




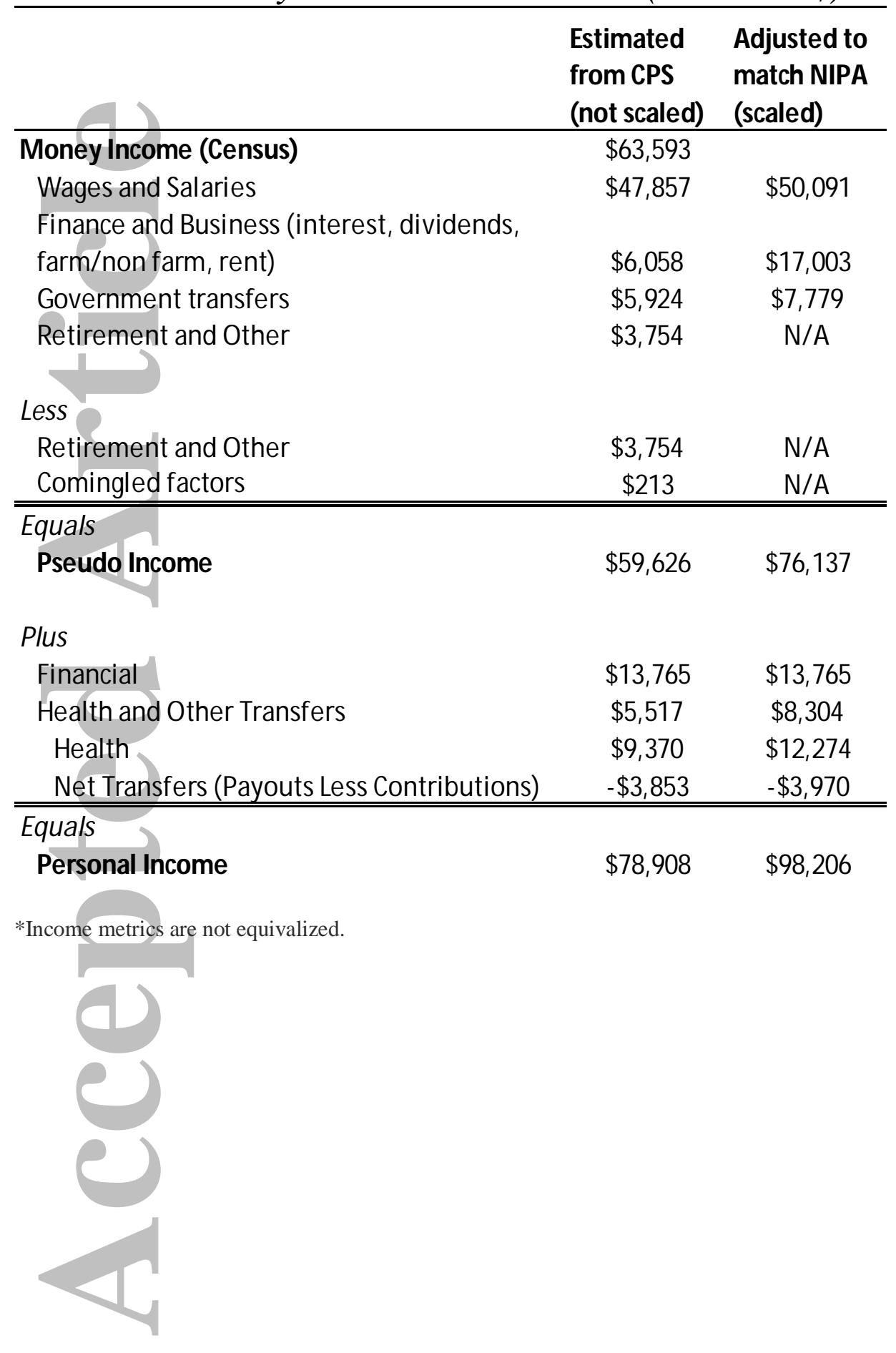


Table 3: Money, Pseudo and Personal Income at various percentiles, 2000-2012 (2006\$)*

\begin{tabular}{|c|c|c|c|c|c|}
\hline & \multicolumn{5}{|c|}{ Money Income (Census) } \\
\hline Year & Average & 10th Percentile & Median & 90th Percentile & 95th Percentile \\
\hline 2000 & $\$ 64,976$ & $\$ 12,044$ & $\$ 47,896$ & $\$ 127,671$ & $\$ 167,847$ \\
\hline 2001 & $\$ 65,035$ & $\$ 11,886$ & $\$ 47,093$ & $\$ 128,008$ & $\$ 169,203$ \\
\hline 2002 & $\$ 63,782$ & $\$ 11,671$ & $\$ 46,752$ & $\$ 126,447$ & $\$ 165,928$ \\
\hline 2003 & $\$ 63,871$ & $\$ 11,358$ & $\$ 46,687$ & $\$ 128,360$ & $\$ 167,501$ \\
\hline 2004 & $\$ 63,818$ & $\$ 11,500$ & $\$ 46,568$ & $\$ 127,792$ & $\$ 165,993$ \\
\hline 2005 & $\$ 64,996$ & $\$ 11,551$ & $\$ 47,232$ & $\$ 130,231$ & $\$ 170,441$ \\
\hline 2006 & $\$ 66,531$ & $\$ 12,000$ & $\$ 48,020$ & $\$ 133,726$ & $\$ 174,020$ \\
\hline 2007 & $\$ 65,968$ & $\$ 11,846$ & $\$ 48,778$ & $\$ 133,101$ & $\$ 172,668$ \\
\hline 2008 & $\$ 64,761$ & $\$ 11,509$ & $\$ 47,334$ & $\$ 131,374$ & $\$ 170,401$ \\
\hline 2009 & $\$ 64,371$ & $\$ 11,470$ & $\$ 47,175$ & $\$ 130,726$ & $\$ 170,512$ \\
\hline 2010 & $\$ 62,903$ & $\$ 11,082$ & $\$ 45,887$ & $\$ 129,541$ & $\$ 168,656$ \\
\hline 2011 & $\$ 63,362$ & $\$ 10,915$ & $\$ 45,478$ & $\$ 130,511$ & $\$ 169,410$ \\
\hline 2012 & $\$ 63,593$ & $\$ 10,910$ & $\$ 44,931$ & $\$ 130,400$ & $\$ 170,690$ \\
\hline \multirow[t]{2}{*}{$\begin{array}{l}\text { Percent } \\
\text { Change }\end{array}$} & $-2.1 \%$ & $-9.4 \%$ & $-6.2 \%$ & $2.1 \%$ & $1.7 \%$ \\
\hline & \multicolumn{5}{|c|}{$\begin{array}{c}\text { Pseudo Money Income } \\
\end{array}$} \\
\hline Year & Average & 10th Percentile & Median & 90th Percentile & 95th Percentile \\
\hline 2000 & $\$ 72,278$ & $\$ 11,962$ & $\$ 49,763$ & $\$ 144,897$ & $\$ 198,033$ \\
\hline 2001 & $\$ 71,829$ & $\$ 11,747$ & $\$ 48,296$ & $\$ 144,019$ & $\$ 201,715$ \\
\hline 2002 & $\$ 70,520$ & $\$ 11,470$ & $\$ 47,569$ & $\$ 141,900$ & $\$ 196,643$ \\
\hline 2003 & $\$ 71,058$ & $\$ 11,389$ & $\$ 47,695$ & $\$ 145,346$ & $\$ 200,678$ \\
\hline 2004 & $\$ 72,388$ & $\$ 11,297$ & $\$ 48,208$ & $\$ 148,001$ & $\$ 205,177$ \\
\hline 2005 & $\$ 73,894$ & $\$ 11,537$ & $\$ 49,311$ & $\$ 149,828$ & $\$ 210,671$ \\
\hline 2006 & $\$ 77,231$ & $\$ 12,152$ & $\$ 51,000$ & $\$ 156,751$ & $\$ 220,327$ \\
\hline 2007 & $\$ 78,863$ & $\$ 12,293$ & $\$ 52,434$ & $\$ 162,682$ & $\$ 227,986$ \\
\hline 2008 & $\$ 78,425$ & $\$ 11,974$ & $\$ 51,241$ & $\$ 158,476$ & $\$ 223,676$ \\
\hline 2009 & $\$ 73,913$ & $\$ 11,737$ & $\$ 48,969$ & $\$ 151,713$ & $\$ 210,981$ \\
\hline 2010 & $\$ 73,562$ & $\$ 11,533$ & $\$ 48,706$ & $\$ 151,873$ & $\$ 210,378$ \\
\hline 2011 & $\$ 74,319$ & $\$ 11,063$ & $\$ 47,366$ & $\$ 152,661$ & $\$ 211,464$ \\
\hline 2012 & $\$ 76,137$ & $\$ 11,123$ & $\$ 48,168$ & $\$ 157,571$ & $\$ 221,779$ \\
\hline \multirow{2}{*}{$\begin{array}{l}\text { Percent } \\
\text { Change }\end{array}$} & $5.3 \%$ & $-7.0 \%$ & $-3.2 \%$ & $8.7 \%$ & $12.0 \%$ \\
\hline & \multicolumn{5}{|c|}{ Personal Income } \\
\hline Year & Average & 10th Percentile & Median & 90th Percentile & 95th Percentile \\
\hline 2000 & $\$ 89,908$ & $\$ 20,477$ & $\$ 64,438$ & $\$ 174,769$ & $\$ 239,425$ \\
\hline 2001 & $\$ 89,698$ & $\$ 21,042$ & $\$ 64,090$ & $\$ 173,583$ & $\$ 235,800$ \\
\hline 2002 & $\$ 88,195$ & $\$ 20,922$ & $\$ 63,211$ & $\$ 169,981$ & $\$ 232,736$ \\
\hline 2003 & $\$ 88,937$ & $\$ 20,578$ & $\$ 63,094$ & $\$ 175,367$ & $\$ 237,662$ \\
\hline 2004 & $\$ 90,706$ & $\$ 20,283$ & $\$ 63,748$ & $\$ 179,573$ & $\$ 241,839$ \\
\hline 2005 & $\$ 92,480$ & $\$ 20,982$ & $\$ 65,023$ & $\$ 180,954$ & $\$ 247,449$ \\
\hline 2006 & $\$ 95,119$ & $\$ 21,775$ & $\$ 65,570$ & $\$ 185,814$ & $\$ 256,372$ \\
\hline 2007 & $\$ 97,351$ & $\$ 22,242$ & $\$ 68,058$ & $\$ 193,286$ & $\$ 265,682$ \\
\hline 2008 & $\$ 97,713$ & $\$ 22,177$ & $\$ 67,839$ & $\$ 190,550$ & $\$ 264,611$ \\
\hline 2009 & $\$ 94,289$ & $\$ 22,860$ & $\$ 66,916$ & $\$ 186,895$ & $\$ 252,581$ \\
\hline 2010 & $\$ 95,165$ & $\$ 22,652$ & $\$ 67,611$ & $\$ 188,376$ & $\$ 256,217$ \\
\hline 2011 & $\$ 96,718$ & $\$ 22,280$ & $\$ 67,145$ & $\$ 188,286$ & $\$ 258,200$ \\
\hline 2012 & $\$ 98,206$ & $\$ 22,228$ & $\$ 67,028$ & $\$ 193,451$ & $\$ 267,297$ \\
\hline $\begin{array}{l}\text { Percent } \\
\text { Change }\end{array}$ & $9.2 \%$ & $8.5 \%$ & $4.0 \%$ & $10.7 \%$ & $11.6 \%$ \\
\hline
\end{tabular}

*Income metrics are not equivalized. 
Figure 3: Shares of quintiles (and top 5 percent) using Personal Income, 2000-2012*

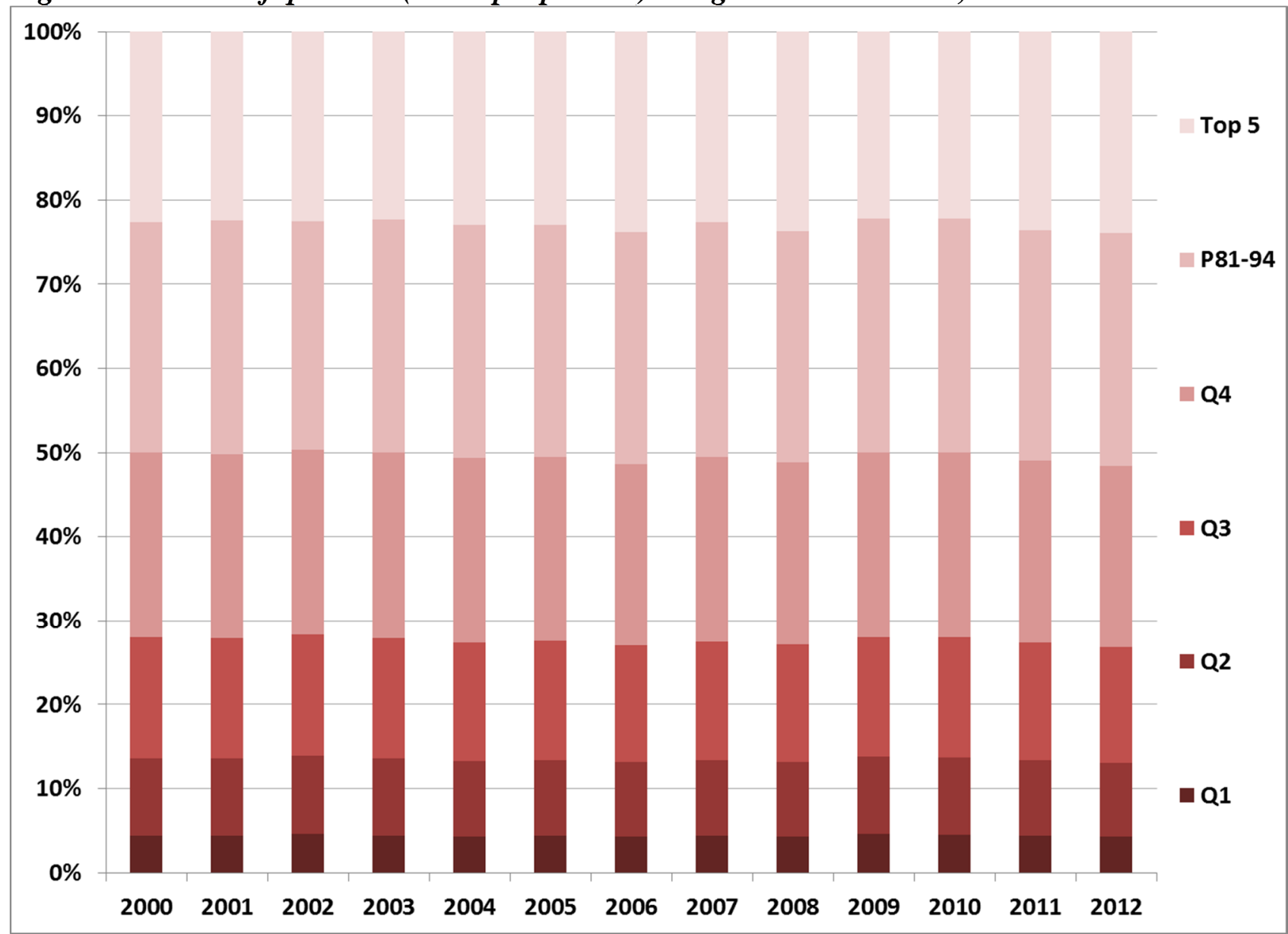

*Income metrics are not equivalized.

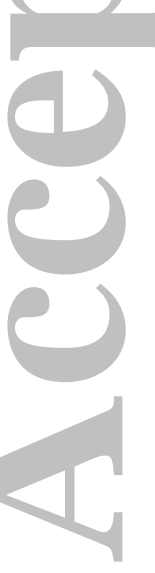


Figure 4: Growth in Personal Income for top 5 percent and bottom 95 percent*

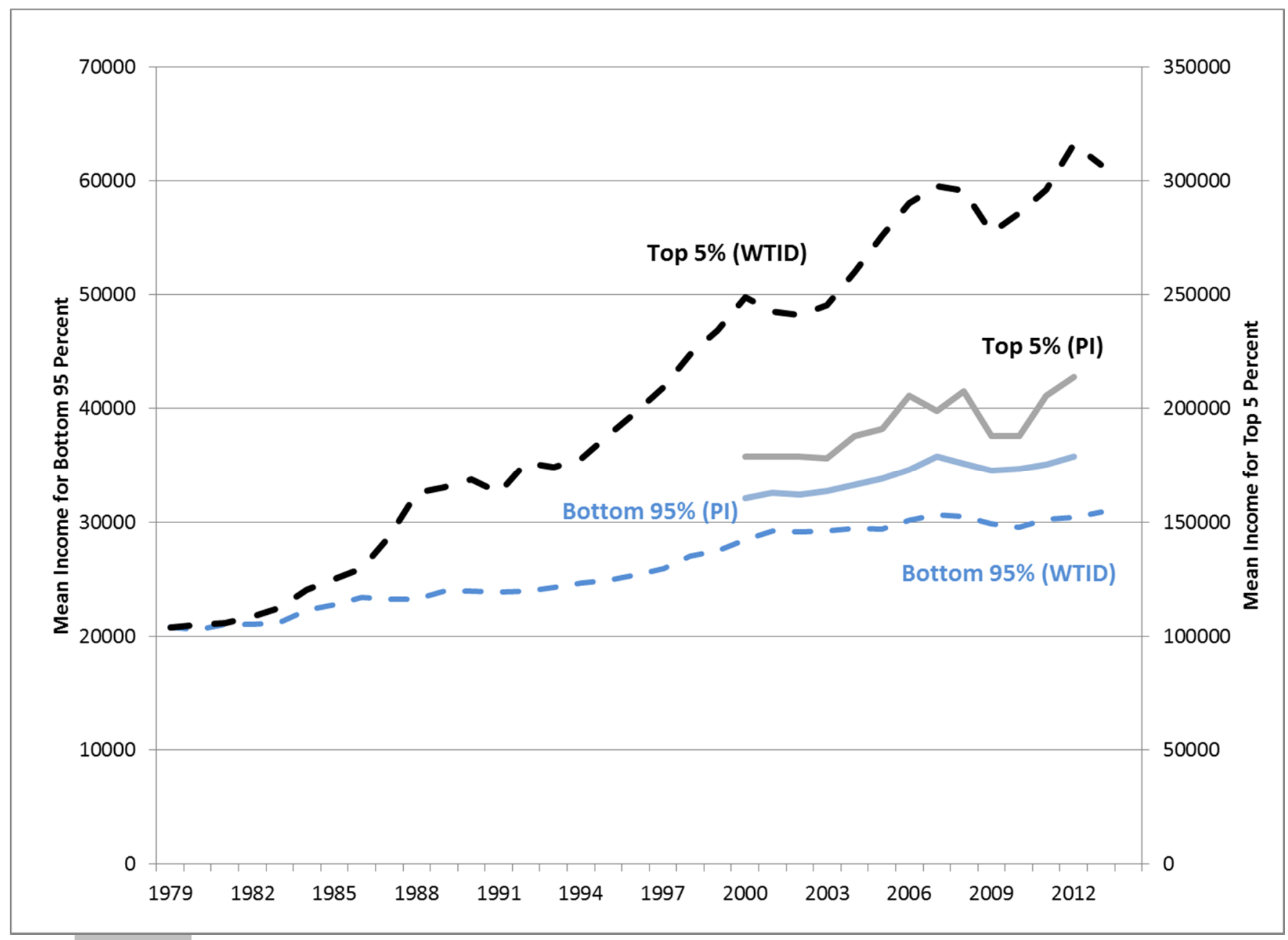

*Income metrics are not equivalized.

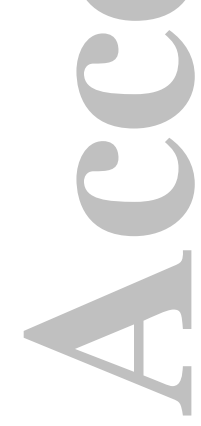

This article is protected by copyright. All rights reserved. 
Figure 5: Gini Coefficient and GDP per capita, 2000-2012*

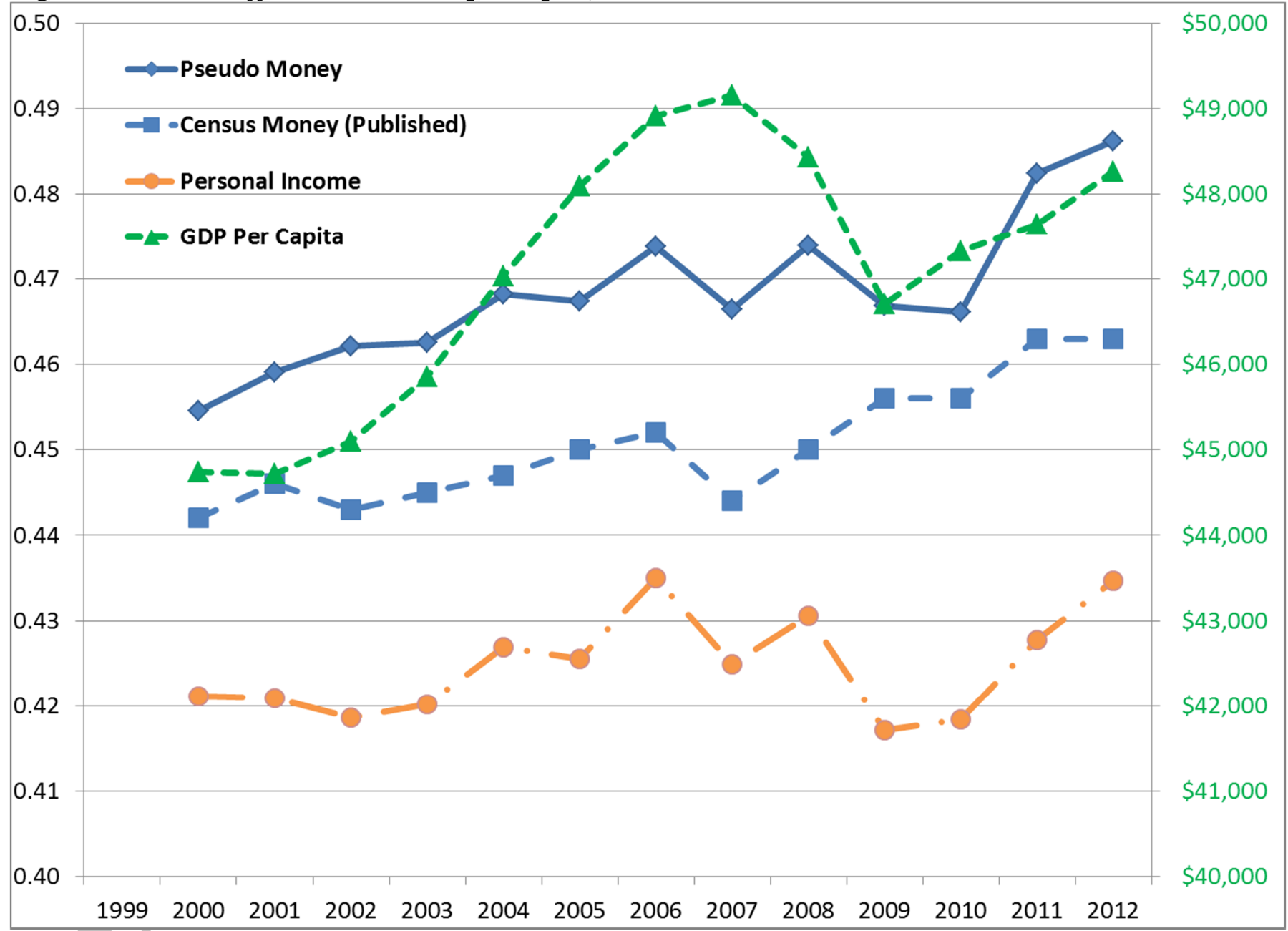

*Income metrics are equivalized based on the square root of family size. 
Figure 6a: Effects of income components on Gini coefficient, 2000-2012*

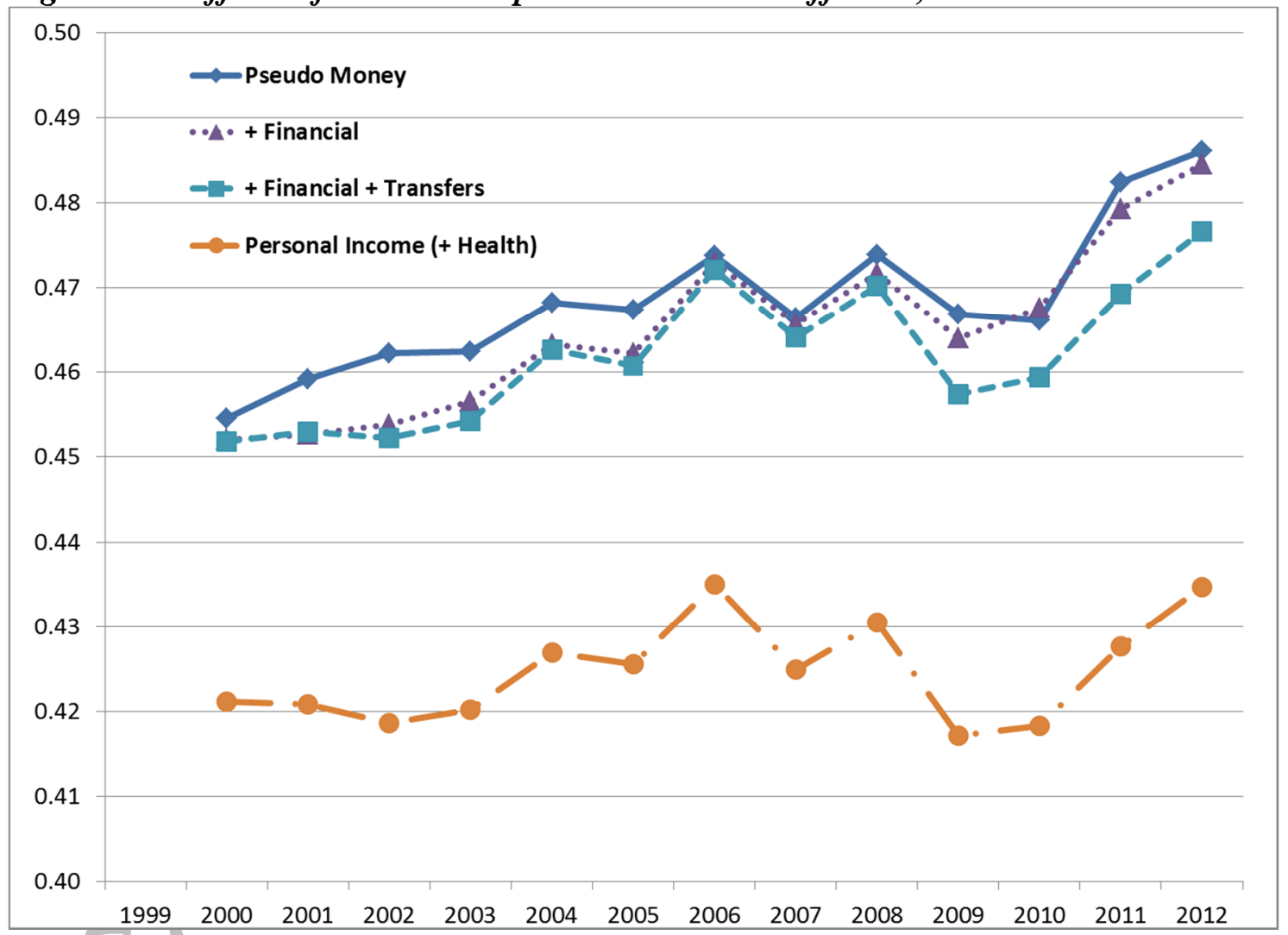

*Income metrics are equivalized based on the square root of family size.

Figure 6b: Social Welfare Function, 2000-2012*

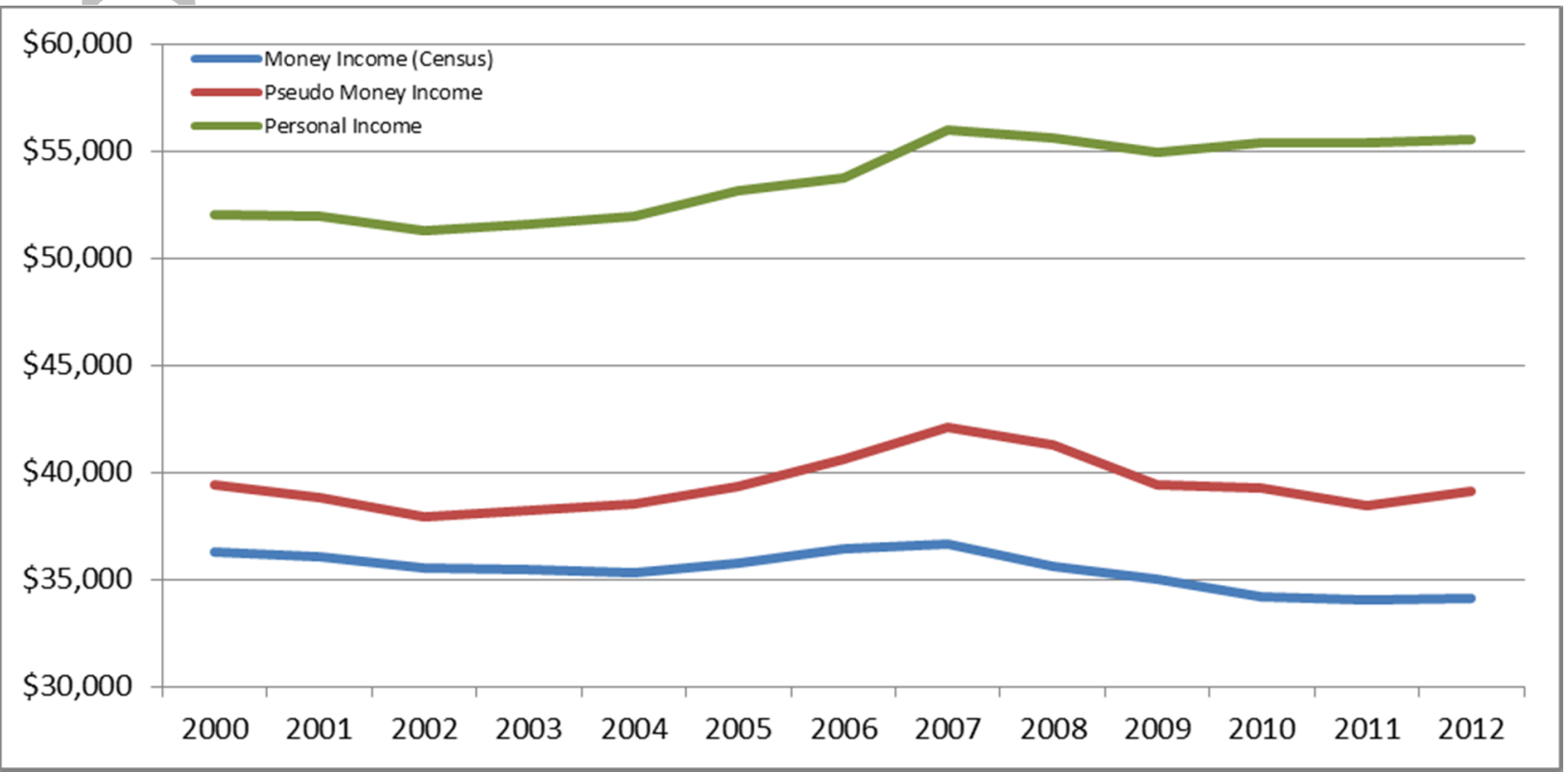

*Income metrics are equivalized based on the square root of family size.

This article is protected by copyright. All rights reserved. 
Figure 7: Median Income by age for Money, Pseudo and Personal Income, 2012 (in 2006\$)*

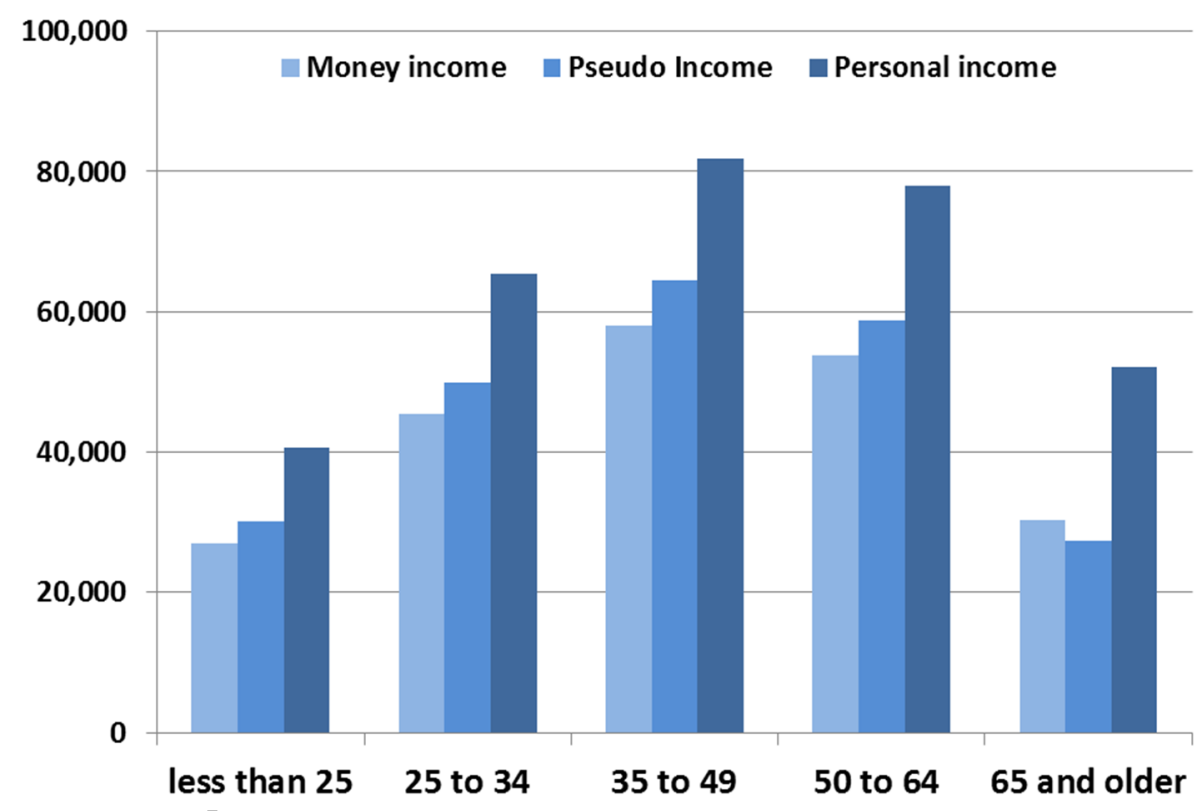

*Income metrics are equivalized based on the square root of family size.

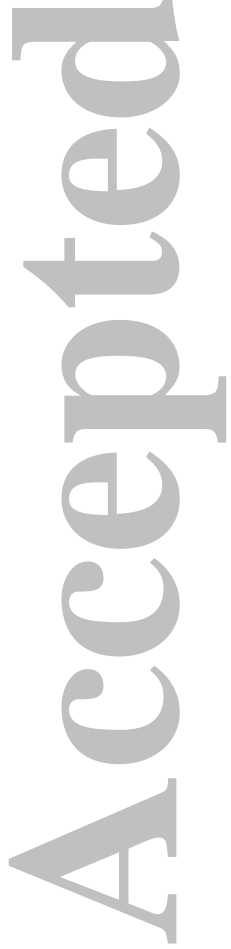

